\title{
Penelitian
}

\section{GAMBARAN PENGETAHUAN IBU DAN POLA ASUH DALAM PEMBERIAN MAKAN DENGAN STATUS GIZI PADA BALITA DI KECAMATAN KERTOSONO, KABUPATEN NGANJUK}

\author{
Cintya Della Widyanata', Yuni Sufyanti Arief', and Iqlima Dwi \\ Kurnia ${ }^{1}$ \\ Fakultas Keperawatan, Universitas Airlangga, Surabaya, Jawa \\ Timur, Indonesia
}

\begin{abstract}
ABSTRAK
Pendahuluan: Status gizi kurang saat ini menjadi masalah universal yang dihadapi di seluruh dunia, terutama Indonesia memiliki masalah gizi yang kompleks. Balita merupakan kelompok usia yang rentan terhadap kelainan gizi sebab usia tersebut membutuhkan gizi lebih besar untuk masa pertumbuhan. Tujuan dari penelitian ini adalah untuk menganalisis hubungan pengetahuan ibu dan pola asuh dalam pemberian makan dengan status gizi pada balita.

Metode:. Penelitian ini menggunakan desain cross-sectional. Penelitian ini dilaksanakan pada tanggal 29 Juni - 4 Juli 2019 di enam Posyandu Desa yang berada di Kecamatan Kertosono dan sampel terdiri dari 114 responden yaitu ibu dan balita yang memenuhi kriteria penelitian dengan teknik pengambilan sampel menggunakan simple random sampling. Variabel independen dalam penelitian ini adalah pengetahuan ibu dan pola asuh dalam pemberian makan yang diukur menggunakan kuesioner yaitu terdiri dari 15 pertanyaan "Benar" dan "Salah" dan 15 pertanyaan yang dikembangkan oleh peneliti berdasarkan Parental Style and Dimension Questionnaire (PSDQ) yang dibuat oleh Robinson et al. (2001) dan variabel dependen penelitian ini yaitu status gizi balita diukur berdasarkan penilaian status gizi dari WHO sesuai indikator BB/U. Data dianalisis menggunakan uji Spearman's rho dan Chi- square dengan tingkat kemaknaan $\rho=0,05$.

Hasil: Hasil penelitian didapatkan sebagian besar ibu memiliki pengetahuan yang kurang sebanyak 64 orang $(56,1 \%)$, sebanyak 91 orang $(79,8 \%)$ menerapkan pola asuh demokratif, sedangkan 11 responden $(9,6 \%)$ menerapkan pola asuh otoriter dan sebanyak 12 orang $(10,5 \%)$ dengan pola asuh permisif dan status gizi balita usia 1-3 tahun memiliki gizi baik atau normal sebanyak 59 orang $(51,8 \%)$.

Kesimpulan: Sebagian besar ibu dengan pengetahuan kurang tentang gizi memiliki balita dengan status gizi kurang dan ibu menerapkan pola asuh demokratif dengan status gizi baik pada balita, hal tersebut menunjukkan bahwa perlu dilakukan edukasi mengenai pentingnya gizi untuk meningkatkan kesehatan dan kesejahteraan anak.
\end{abstract}

Kata kunci: pengetahuan, pola asuh dalam pemberian makan, status gizi

\section{ABSTRACT}

Introduction: Poor nutritional status is now a universal problem faced throughout the world, especially Indonesia has complex nutritional problems. Toddler is an age group that was susceptible to nutritional disorders because that age requires greater nutrition for growth period. The purpose of this study was to analyze the relationship between knowledge and parenting in feeding with nutritional status in toddler.

Methods: This study used a cross-sectional design. This research was conducted on 29 June - 4 July 2019 in six integrated healthare center located in Kertosono District and the sample consisted of 114 respondents, namely mothers and toddlers who met the research criteria with the sampling technique using simple random sampling. The independent variable in this study were the knowledge and parenting style of feeding which was measured used a questionnaire consisting of 15 "True" and "False" questions and 15 questions developed by researchers based on the Parental Style and Dimension 
Questionnaire (PSDQ) made by Robinson. et al. (2001) and the dependent variable of this study was the nutritional status of children measured by the assessment of nutritional status of the WHO is BB/U. Data were analyzed used the Spearman's rho and Chisquare test with significance level $\rho=0.05$.

Result: The results showed that most mothers had less knowledge as many as 64 people (56.1\%), as many as 91 people (79.8\%) applied democratic parenting, while 11 respondents (9.6\%) applied authoritarian parenting and as many as 1259 people (10.5\%) with permissive parenting and nutritional status of children aged 1-3 years had good or normal nutrition (51.8\%).

Conclusion: Most mothers with insufficient knowledge about nutrition have toddlers with poor nutritional status and mothers applied democratic parenting with good nutritional status for toddlers, this showed that education needs to be done on the importance of nutrition to improve children's health and welfare.

Keywords: knowledge, parenting in feeding, nutritional statu

\section{PENDAHULUAN}

Status gizi kurang saat ini menjadi masalah universal yang dihadapi di seluruh dunia, terutama Indonesia memiliki masalah gizi yang kompleks. Gizi kurang merupakan kondisi yang abnormal karena kekurangan atau ketidakseimbangan antara energi, protein dan nutrisi lainnya ${ }^{[1]}$. Balita merupakan kelompok usia yang sangat rentan terhadap kelainan gizi sebab pada usia tersebut kebutuhan gizi dibutuhkan lebih besar untuk masa pertumbuhan, baik fisik maupun otak sehingga diperlukan pola asuh dalam pemberian makan yang baik. Penelitian ini menggunakan indikator status gizi pada balita yang berusia 1-3 tahun berdasarkan BB/U. Berdasarkan studi pendahuluan dilakukan pada 1 April 2019, didapatkan enam dari 14 desa yang berada di Kertosono memiliki angka kejadian gizi kurang pada balita cukup tinggi. Teknik pengambilan sampel menggunakan simple random sampling. Terdapat 23 ibu di Desa Pelem memiliki pengetahuan kurang tentang pemberian makan berdasarkan konsep gizi seimbang dan cara pengolahan bahan makanan. Selain itu, 23 ibu juga memiliki pola asuh yang kurang baik, dimana lebih memilih untuk memberikan makanan cepat saji terhadap anak dan kebiasaan memakan makanan yang kurang tepat seperti bermain atau menonton tv. Oleh karena itu, faktor pengetahuan dan pola asuh ibu dalam pemberian makan perlu penelitian lebih lanjut.

Data World Health Organization (2018) menyatakan bahwa $36,4 \%$ balita Indonesia mengalami stunting, sekitar
$13,5 \%$ wasting dan $11,5 \%$ dengan overweight. Berdasarkan hasil Riset Kesehatan Dasar (2018) menyatakan bahwa angka kejadian gizi mencapai $17,7 \%$ dimana terdiri dari gizi buruk sebesar $3,9 \%$ dan gizi kurang mencapai $13,8 \%$ serta hal ini menunjukkan penurunan angka kejadian dari tahun 2013, gizi buruk sekitar 5,7\% dan gizi kurang sebesar $13,9 \%{ }^{[10]}$. Tahun 2017 , dari 2.319.878 balita yang ditimbang terdapat $17.085(0,7 \%)$ balita Bawah Garis Merah (BGM) di wilayah Jawa Timur $^{[8]}$ dan balita dengan gizi lebih sebesar 2,2\% sedangkan gizi normal sebesar 82,3\%. Menurut Data Dinkes Kabupaten Nganjuk balita dengan status BGM mengalami kenaikan dari tahun 2017-2018. Data ${ }^{[7]}$ dari 62.256 balita yang ditimbang terdapat $503 \quad(0,8 \%)$ sedangkan tahun 2018 dari 61.180 balita yang ditimbang diperoleh 532 $(0,87 \%)$ berstatus BGM. Kabupaten Nganjuk terdiri dari 20 Kecamatan, salah satunya adalah Kecamatan Kertosono. Kertosono menduduki peringkat 10 besar balita BGM dengan prosentase sebesar $0,98 \%$ di tahun 2018. Berdasarkan hasil penimbangan Puskesmas Kertosono tahun 2018 didapatkan rata-rata sekitar 201 balita $(6,22 \%)$ dengan gizi kurang dari 3.669 balita sedangkan balita BGM sebesar 29 balita dengan prosentase $0,9 \%$.

$$
\text { Adapun }
$$

faktor yang

mempengaruhi status gizi meliputi faktor langsung dan faktor tidak langsung. Faktor langsung terdiri dari asupan nutrisi dan penyakit infeksi sedangkan faktor tidak langsung meliputi ketahanan pangan dikeluarga, pola pengasuhan anak, serta pelayanan kesehatan dan 
lingkungan ${ }^{[21]}$. Balita dengan masalah gizi kurang akan berdampak pada keterlambatan pertumbuhan dan perkembangan anak seperti fisik, psikomotor dan mental serta dapat menyebabkan penurunan sel otak ${ }^{[11]}$. Kekurangan gizi disebabkan oleh pola asuh orang tua terutama ibu yang menjadi faktor dalam pemilihan makanan yang tidak benar. Ketepatan memilih bahan makanan, kecukupan jumlah dan keanekaragaman dalam makanan dapat dipengaruhi oleh tingkat pengetahuan ibu mengenai kandungan gizi. Kesalahan dalam memilih makanan pada balita disebabkan karena ketidaktahuan ibu terhadap kebutuhan asupan nutrisi yang dikonsumsi ${ }^{[16]}$.

$\begin{array}{ccr}\text { Upaya } & \text { Dinas } & \text { Kesehatan } \\ \text { Kabupaten } & \text { Nganjuk } & \text { telah }\end{array}$ mencanangkan gerakan untuk mengatasi kasus gizi buruk melalui program gerakan pengentasan gizi buruk (GENTASIBU) berupa Pemberian Makanan Tambahan-Pemulihan (PMT$P)$, pemeriksaan dokter, konseling gizi serta pendampingan kader. Namun, hasil evaluasi dari program tersebut masih ditemukan kejadian yang berhubungan dengan status gizi pada balita. Berdasarkan uraian diatas, untuk mengantisipasi agar tidak terjadi gizi kurang cukup tinggi, penulis tertarik melakukan penelitian guna mengetahui hubungan pengetahuan dan pola asuh pemberian makan dengan status gizi pada balita.

\section{METOLOGI PENELITIAN}

Desain pada penelitian in
menggunakan pendekatan cross sectional yaitu menekankan pengukuran/observasi data variabel dalam satu kali pada satu waktu ${ }^{[13]}$. Penelitian ini dilakukan pada 29 Juni -4 Juli 2019. Populasi dalam penelitian ini adalah ibu dan balita usia 1-3 tahun di Puskesmas Kertosono berjumlah 1.135 orang. Sampel dalam penelitian ini dengan kriteria inklusi yaitu lbu dan balita (usia 1-3 tahun) berjumlah 114 orang, ibu yang aktif menimbang balita di Posyandu, dapat berkomunikasi lisan dan tertulis. Kriteria eksklusi yaitu ibu dan balita yang dalam keadaan sakit seperti diare dan ISPA berdasarkan informasi dari puskesmas sehingga tidak dapat mengikuti Posyandu dan responden yang menolak untuk | BIMIKI | Volume 8 No 2 Juli - Desember 2020 berpartisipasi. Teknik sampling yang digunakan adalah simple random sampling.

Variabel independen pada penelitian ini pengetahuan dan pola asuh dalam pemberian makan. Variabel dependen pada penelitian ini adalah status gizi.

Instrumen yang digunakan pada penelitian meliputi kuesioner data demografi, kuesioner pengetahuan, kuesioner pola asuh dalam pemberian makan dan pengukuran status gizi berdasarkan $\mathrm{BB} / \mathrm{U}$ sesuai grafik WHO. Kuesioner data demografi terdiri dari nomor responden, tanggal pengambilan data, usia, pendidikan terakhir, jenis pekerjaan, penghasilan keluarga, jumlah anak, usia balita, jenis kelamin balita, berat badan balita. Kuesioner pengetahuan terdiri dari 15 pertanyaan "Benar" dan "Salah" yang dikembangkan oleh peneliti dan sudah dilakukan uji validitas dan realibilitas. Pertanyaan tersebut mengidentifikasi pengetahuan tentang pemberian makan meliputi gizi seimbang, kandungan gizi, cara pengolahan makanan dan konsep status gizi. Kuesioner pola asuh dalam pemberian makan terdiri dari 15 pertanyaan. Kuesioner ini dikembangkan oleh peneliti berdasarkan Parental Style and Dimension Questionnaire (PSDQ) yang dibuat oleh Robinson et al. (2001). Kuesioner diukur menggunakan skala likert, dimana jawabannya terdiri dari selalu, sering, kadang-kadang, sesekali, dan tidak pernah. Pernyataan yang diajukan berjumlah 15 soal dan sudah dilakukan uji validitas da realibiltas.

Analisis data yang digunakan dalam penelitian ini yaitu menggunakan Analisa deskriptif dan Analisa inferensial. Uji yang digunakan pada penelitian ini adalah uji statistik Spearman dan Chi-square test yang ditujukan untuk mengetahui hubungan antara dua atau lebih variabel.

Penelitian ini dilakukan sesuai dengan etika penelitian dimana sebelum melakukan penelitian, peneliti perlu mendapat persetujuan dari pihak terkait. Proseddur yang berhubungan dengan etika penelitian meliputi surat persetujuan (informed consent), tanpa nama (anonymity), kerahasiaan (confidentiality), keadilan (justice). 
Penelitian ini sudah melakukan uji etik ke bagian Komite Etik Penelitian Kesehatan (KEPK) Fakultas Keperawatan Universitas Airlangga Surabaya dan dinyatakan telah lulus uji etik dengan Nomor sertifikat etik 1509KEPK.

HASIL

Data karakteristik demografi pada penelitian ini meliputi usia, pendidikan terakhir ibu, pekerjaan ibu, penghasilan keluarga, jumlah anak dan jenis kelamin balita. Berdasarkan tabel 1 menunjukkan bahwa sebagian besar responden berusia 20-35 tahun (usia dewasa awal) sebanyak 87 orang $(76,3 \%)$. Dilihat dari segi pendidikan terakhir sebanyak 67 responden dengan kategori SMA (58,8\%). Mayoritas 97 responden bekerja sebagai ibu rumah tangga (85,1\%), sebanyak 65 responden dengan penghasilan keluarga $\leq$ UMK Kabupaten Nganjuk pada tahun $2019(57 \%)$. Selain itu, 57 responden memiliki 2 orang anak $(57 \%)$ dan terdapat 57 responden balita (50\%) yang berjenis kelamin perempuan serta 57 responden dengan jenis kelamin lakilaki (50\%).

Hasil distribusi pengetahuan ibu tentang gizi, berdasarkan tabel 2 menunjukkan bahwa sebagian besar responden memiliki pengetahuan yang kurang berdasarkan prinsip gizi seimbang, kandungan gizi, cara pengolahan makanan dan konsep status gizi sebanyak 64 orang $(56,1 \%)$. 
Tabel 1. Karakteristik data demografi

\begin{tabular}{|c|c|c|c|c|}
\hline No. & Karakteristik & Kategori & Frekuensi & $\%$ \\
\hline \multirow[t]{4}{*}{1} & Usia ibu & $<20$ tahun & 1 & 0,9 \\
\hline & & 20-35 tahun & 87 & 76,3 \\
\hline & & $>35$ tahun & 26 & 22,8 \\
\hline & Total & & 114 & 100 \\
\hline \multirow[t]{5}{*}{2} & Pendidikan terakhir ibu & SD/sederajat & 6 & 5,3 \\
\hline & & SMP/sederajat & 29 & 25,4 \\
\hline & & SMA/sederajat & 67 & 58,8 \\
\hline & & Perguruan Tinggi & 12 & 10,5 \\
\hline & Total & & 114 & 100 \\
\hline \multirow[t]{5}{*}{3} & Pekerjaan ibu & Ibu rumah tangga & 97 & 85,1 \\
\hline & & Pegawai negeri & 1 & 0,9 \\
\hline & & Pegawai swasta & 9 & 7,9 \\
\hline & & Wiraswasta & 7 & 6,1 \\
\hline & Total & & 114 & 100 \\
\hline \multirow[t]{3}{*}{4} & Penghasilan keluarga & $\leq \mathrm{UMK}$ & 65 & 57 \\
\hline & & $\geq$ UMK & 49 & 43 \\
\hline & Total & & 114 & 100 \\
\hline \multirow[t]{4}{*}{5} & Jumlah anak & 1 orang & 41 & 36 \\
\hline & & 2 orang & 57 & 50 \\
\hline & & $>2$ orang & 16 & 14 \\
\hline & Total & & 114 & 100 \\
\hline \multirow[t]{3}{*}{6} & Jenis kelamin balita & Laki-laki & 57 & 50 \\
\hline & & Perempuan & 57 & 50 \\
\hline & Total & & 114 & 100 \\
\hline
\end{tabular}

Tabel 2. Distribusi data pengetahuan ibu

\begin{tabular}{llc}
\hline Kategori Pengetahuan Ibu & $\mathbf{f}$ & $\%$ \\
\hline Kurang & 64 & 56,1 \\
Cukup & 34 & 29,8 \\
\hline
\end{tabular}


E - ISSN : $2722-127 \mathrm{X}$

P - ISSN : 2338 - 4700

Baik

Berdasarkan tabel 3 menunjukkan distribusi status gizi balita yaitu mayoritas balita usia 1-3 tahun memiliki gizi baik atau normal sebanyak 59 orang $(51,8 \%)$, 40 orang $(35,1 \%)$ dengan gizi kurang dan 15 orang $(13,2 \%)$ dengan status gizi lebih. Hasil distribusi data pola asuh dalam pemberian makan ditunjukkan pada tabel 4 yaitu mayoritas responden sebanyak 91 orang $(79,8 \%)$ menerapkan pola asuh demokratif, sedangkan 11 responden $(9,6 \%)$ menerapkan pola asuh otoriter dan sebanyak 12 orang $(10,5 \%)$ dengan pola asuh permisif.

Berdasarkan tabel 5, hasil uji statistik menggunakan Sperman's Rho

Tabel 3. Distribusi data status gizi balita

\begin{tabular}{lcc}
\hline Kategori Status Gizi & $\mathbf{f}$ & $\%$ \\
\hline Gizi Kurang & 40 & 35,1 \\
Gizi Baik & 59 & 51,8 \\
Gizi Lebih & 15 & 13,2 \\
\hline Total & $\mathbf{1 1 4}$ & $\mathbf{1 0 0}$ \\
\hline
\end{tabular}

Tabel 4. Distribusi data pola asuh dalam pemberian makan

\begin{tabular}{lcc}
\hline Kategori Pola Asuh dalam Pemberian Makan & $\mathbf{f}$ & $\%$ \\
\hline Pola asuh otoriter & 11 & 9,6 \\
Pola asuh demokratif & 91 & 79,8 \\
Pola asuh permisif & 12 & 10,5 \\
\hline Total & $\mathbf{1 1 4}$ & $\mathbf{1 0 0}$
\end{tabular}

Tabel 5. Analisis hubungan antara pengetahuan dengan status gizi pada balita di Kecamatan Kertosono, Kabupaten Nganjuk.

\begin{tabular}{|c|c|c|c|c|c|c|c|}
\hline \multirow{3}{*}{$\begin{array}{c}\text { Pengetahuan } \\
\text { ibu }\end{array}$} & \multicolumn{5}{|c|}{ Status gizi } & \multirow{2}{*}{\multicolumn{2}{|c|}{ Total }} \\
\hline & Gizi Kurang & \multicolumn{2}{|c|}{ Gizi Baik } & \multicolumn{2}{|c|}{ Gizi Lebih } & & \\
\hline & $\%$ & $f$ & $\%$ & $f$ & $\%$ & $\mathbb{E}$ & $\%$ \\
\hline
\end{tabular}

(r5) diperoleh derajat signifikasi sebesar $\mathrm{p}=0,001$ dengan menetapkan derajat signifikasi $\alpha \leq 0,05$. Koefisien korelasi didapatkan nilai 0,307 yang berarti tingkat hubungan lemah. Berdasarkan hasil tersebut, dapat dikatakan bahwa pengetahuan ibu berhubungan dengan status gizi balita. Sedangkan, hasil uji statistik menggunakan Chi Square pada tabel 6 menunjukkan tidak terdapat hubungan $(p=0,662)$ antara pola asuh dalam pemberian makan dengan status gizi balita. 


\begin{tabular}{lcccccccc}
\hline Kurang & 31 & 27,2 & 25 & 21,9 & 8 & 7,0 & 64 & 56,1 \\
\hline Cukup & 7 & 6,1 & 27 & 23,7 & 0 & 0,0 & 34 & 29,8 \\
\hline Baik & 2 & 1,8 & 7 & 6,1 & 7 & 6,1 & 16 & 14,0 \\
\hline Total & $\mathbf{4 0}$ & $\mathbf{3 5 , 1}$ & $\mathbf{5 9}$ & $\mathbf{5 1 , 8}$ & $\mathbf{1 5}$ & $\mathbf{1 3 , 2}$ & $\mathbf{1 1 4}$ & $\mathbf{1 0 0 , 0}$ \\
\hline \multicolumn{7}{c}{ Spearman's rho } & $\mathrm{p}=0,001 ; r=0,307$ & \\
\hline
\end{tabular}

Tabel 6. Analisis hubungan antara pola asuh dalam pemberian makan dengan status gizi pada balita di Kecamatan Kertosono, Kabupaten Nganjuk.

\begin{tabular}{|c|c|c|c|c|c|c|c|c|c|}
\hline \multirow{3}{*}{$\begin{array}{c}\text { Variabel } \\
\text { Independen }\end{array}$} & \multirow[t]{3}{*}{ Kategori } & \multicolumn{6}{|c|}{ Status Gizi } & \multicolumn{2}{|c|}{ Total } \\
\hline & & \multicolumn{2}{|c|}{ Kurang } & \multicolumn{2}{|c|}{ Baik } & \multicolumn{2}{|c|}{ Lebih } & \multirow[b]{2}{*}{$F$} & \multirow[b]{2}{*}{$\%$} \\
\hline & & $f$ & $\%$ & $f$ & $\%$ & $f$ & $\%$ & & \\
\hline \multirow[t]{4}{*}{ Pola Asuh } & Otoriter & 3 & 2,6 & 5 & 4,4 & 3 & 2,6 & 11 & 9,6 \\
\hline & Demokratif & 32 & 28,1 & 48 & 42,1 & 11 & 9,6 & 91 & 79,8 \\
\hline & Permisif & 5 & 4,4 & 6 & 5,3 & 1 & 0,9 & 12 & 10,6 \\
\hline & Total & 40 & 35,1 & 59 & 51,8 & 15 & 13,1 & 114 & 100 \\
\hline
\end{tabular}

\section{PEMBAHASAN}

Pembahasan dalam penelitian ini disajikan dalam bentuk narasi dari hasil penelitian yang dilakukan oleh peneliti.

\subsection{Hubungan pengetahuan dengan status gizi balita}

Hasil penelitian didapatkan data bahwa pengetahuan ibu berhubungan dengan status gizi balita. Ibu yang memiliki pengetahuan kurang menjadi hal paling dominan pada balita dengan status gizi kurang. Pengetahuan ibu tentang gizi seimbang akan mempengaruhi pemilihan dan penyediaan bahan makanan untuk keluarga terutama anak. Memiliki pengetahuan yang memadai dapat meningkatkan status gizi balita terutama anak dibawah lima tahun ${ }^{[21]}$. Sehingga, kurangnya pengetahuan tentang gizi akan menimbulkan masalah gizi yang dapat mengganggu pertumbuhan dan perkembangan anak. Hasil penelitian ini sejalan dengan penelitian yang dilakukan oleh Susanti et al., (2014) menyatakan bahwa terdapat hubungan yang signifikan antara pengetahuan ibu tentang gizi dengan status gizi balita 1-3 tahun ${ }^{[24]}$. Selain itu menurut penelitian oleh Ningsih et al., (2015) menyimpulkan bahwa adanya hubungan antara pengetahuan ibu dalam pemberian nutrisi dengan status gizi kurang anak usia toddler ${ }^{[11]}$.

Terdapat 25 responden anaknya mengalami gizi baik dengan pengetahuan yang kurang. Diukur dari hasil kuesioner bahwa ibu tidak dapat membedakan antara karbohidrat dan protein. Namun, kebutuhan dalam memberikan makan sudah cukup. Pengetahuan ibu tentang gizi seimbang yang kurang tetapi asupan karbohidrat pada anaknya baik dapat disebabkan karena faktor pekerjaan ibu ${ }^{[6]}$. Sehingga, meskipun ibu dengan pengetahuannya kurang tetapi dilihat dari faktor pekerjaan ibu yang sebagian besar responden adalah ibu rumah tangga maka dapat selalu memantau dan memenuhi kebutuhan gizi dari anaknya.

Pengetahuan merupakan hasil dari penginderaan seseorang terhadap suatu obyek tertentu. Sebagian besar 
pengetahuan manusia diperoleh melalui mata dan telinga ${ }^{[12]}$. Namun, terdapat dua responden berpengetahuan baik dengan balita status gizi kurang dikarenakan faktor penghasilan keluarga $\leq U M K$ dan jumlah anak yang lebih dari 2 orang. Faktor ekonomi dapat dikaitkan dengan kemampuan dalam mengakses makanan dimana kemampuan keluarga dalam membeli bahan makanan tidak hanya dipengaruhi oleh besarnya pendapatan tetapi juga harga bahan makanan ${ }^{[17]}$. Ibu dengan pengetahuan gizi yang baik akan mengerti dan memahami pentingnya status gizi normal bagi kesehatan dan kesejahteraan ${ }^{[1]}$. Sehingga, tingkat pengetahuan ibu berperan dalam pengelolaan rumah tangga, karena hal ini akan mempengaruhi sikap ibu dalam memilih bahan makanan yang nantinya akan dikonsumsi oleh keluarga.

Dilihat dari segi pendidikan responden berpendidikan paling tinggi adalah SMA dibandingkan dengan Perguruan Tinggi. Pengetahuan juga berkaitan dengan pendidikan yang ditempuh oleh ibu. Tingkat pendidikan dapat mempengaruhi penerimaan dan penyerapan informasi. Ibu yang memiliki tingkat pendidikan tinggi akan mempunyai pengetahuan luas dan lebih memahami makanan yang baik, serta keragaman bahan makanan untuk anaknya ${ }^{[22]}$. Hal ini menunjukkan bahwa dampak jenjang pendidikan yang rendah akan menyebabkan ibu kurang memahami mengenai pentingnya gizi dan menyerap informasi kesehatan daripada ibu yang memiliki pendidikan tinggi akan lebih mudah menerima, memahami dan dapat mengaplikasikan di keluarganya karena mempunyai pengetahuan yang luas.

Pengetahuan mengenai status gizi merupakan hal yang penting untuk diketahui para ibu karena dapat mengarahkan untuk melakukan pemantauan pertumbuhan dan perkembangan balita, dengan memberikan makanan yang sesuai dengan kebutuhan gizi balita sehingga secara tidak langsung akan mempengaruhi status gizi balita ${ }^{[18]}$. Pengetahuan memfasilitasi seseorang untuk mendapatkan informasi yang bermanfaat dan menerapkan gaya hidup sehat. Pentingnya pemenuhan gizi yang memadai didasarkan pada tiga fakta empiris, yaitu: status nutrisi yang cukup, nutrisi diperlukan untuk pertumbuhan yang optimal baik fisik maupun mental dalam jangka waktu yang lama dan memiiki kesadaran tentang cara mengolah dan mengkonsumsi makanan yang mengandung nutrisi mengingat bahwa balita rentan terhadap kekurangan gizi ${ }^{[9]}$. Pengetahuan yang tidak memadai dan praktik-praktik yang tidak tepat merupakan hambatan signifikan terhadap peningkatan gizi $^{[26]}$.

\subsection{Hubungan pola asuh dalam pemberian makan dengan status gizi balita}

Hasil penelitian didapatkan data bahwa pola asuh dalam pemberian makan tidak berhubungan dengan status gizi balita. Sebagian besar ibu menerapkan pola asuh demokratif dengan status gizi baik pada balita. Pola pengasuhan setiap ibu berbeda dapat dipengaruhi oleh beberapa faktor pendukung antara lain usia ibu, pendidikan, pekerjaan dan jumlah anak. Hasil penelitian ini sesuai dengan penelitian yang dilakukan oleh Astuti, Kapantow \& Ratag (2014) menyatakan bahwa tidak terdapat hubungan antara pola asuh ibu dengan status gizi ${ }^{[3]}$.

Pola asuh merupakan kemampuan keluarga terutama ibu atau pengasuh untuk memberikan waktu, perhatian, dukungan terhadap anak agar dapat tumbuh kembang dengan sebaik-baiknya secara fisik, mental dan sosial ${ }^{[2]}$. Hal tersebut akan membuat tumbuh kembang anak menjadi baik. Pertumbuhan secara fisik, mental dan sosial anak akan mengikuti berdasarkan pola asuh yang baik. Pola asuh dapat dilakukan melalui perilaku ibu ke anak, kedekatan ibu dan anak, pemberian makanan, merawat dan menjaga kebersihan anak ${ }^{[23]}$.

Didapatkan 32 responden menerapkan pola asuh demokratif yang memiliki balita dengan status gizi yang baik, namun di sisi lain masih ditemukan adanya balita dengan status gizi kurang. Pola asuh demokratif dapat dikaitkan dengan 
pemantauan asupan makanan terhadap anak dikarenakan tidak adanya tekanan dan pembatasan dari orang tua sehingga anak dapat mengungkapkan menu makanan apa yang akan ia konsumsi tetapi masih dalam pengontrolan orang tua ${ }^{[5]}$. Sehingga, hal tesebut dapat dilihat dari data distribusi sebagian besar pekerjaan responden adalah lbu rumah tangga. Hal ini dapat mempengaruhi pola asuh ibu dalam pemberian makan dikarenakan ibu dapat mendampingi anaknya ketika ingin makan, mengontrol dan membantu memilih makanan yang akan dikonsumsi oleh anak seperti memberikan makanan yang disukai dengan harapan anak tersebut akan menghabiskan makanannya. Namun, pada kenyataannya masih terdapat ibu dengan pekerjaan sampingan seperti membantu memasak atau mencuci di rumah tetangga. Dikarenakan ibu merasa kurang dalam penghasilan keluarga yang masih di bawah UMK. Sehingga, dapat disimpulkan bahwa kedua faktor tersebut menyebabkan status gizi kurang.

Terdapat 3 responden dengan menerapkan pola asuh otoriter dengan balita gizi kurang. Pola asuh otoriter mengacu pada penekanan akan pentingnya kepatuhan, adanya pengontrolan penuh sesuai keinginan orang tua ${ }^{[25]}$. Hal ini dapat dilihat dari hasil kuesioner yang telah dijawab oleh responden tersebut yaitu selalu mengancam apabila anak tidak mau makan, berusaha keras menyuruh anak makan sesuai dengan menu yang dipilih oleh ibu dan kadang-kadang menunjukkan sikap tidak setuju seperti mencubit atau memarahi ketika anak menolak untuk makan tanpa memperhatikan prinsipprinsip gizi seimbang atau sesuai kebutuhan gizi anak.

Hasil penelitian ini ditemukan sebanyak 6 responden dengan pola asuh permisif dan memiliki balita berstatus gizi baik. Pola asuh permisif merupakan gaya mengasuh dengan tipe pengabaian dimana pola asuh ini akan mengakibatkan anak mengkonsumsi makanan sembarangan tanpa pengawasan orang tua ${ }^{[25]}$. Hal ini dapat dilihat dari data distribusi bahwa pekerjaan dari ibu yaitu pegawai swasta dan wiraswasta dimana dengan ibu yang bekerja dapat memenuhi kebutuhan yang cukup pada anaknya.

Pemberian makan yang baik sangat penting untuk asupan nutrisi, tidak hanya dilihat dari segi makanan yang dikonsumsi oleh anak tetapi sikap ibu untuk mengawasi dalam pemberian makan dapat menujang status gizi balita [15]. Ketika anak mengkonsumsi makanan, diharapkan ibu tetap memperhatikan prinsip-prinsip gizi seimbang dan kandungan gizi yang terdapat pada makanan tersebut. Apabila makanan tidak dipilih dengan benar maka tubuh akan mengalami kekurangan zat gizi maupun kelebihan gizi.

\section{KESIMPULAN}

Kesimpulan dalam penelitian ini adalah pengetahuan ibu yang kurang dapat berhubungan dengan status gizi kurang pada balita dan pola asuh dalam pemberian makan tidak terdapat hubungan dengan status gizi balita.

\section{SARAN}

Bagi peneliti selanjutnya diharapkan dapat memberikan intervensi berupa metode pendidikan kesehatan yang tepat seperti penyuluhan kesehatan atau roleplay untuk meningkatkan pengetahuan orang tua tentang gizi.

\section{UCAPAN TERIMA KASIH}

Puji dan syukur saya panjatkan kehadirat Allah SWT, karena atas berkat dan rahmat-Nya, saya dapat menyelesaikan penelitian ini. Saya menyadari bahwa, tanpa bantuan dan bimbingan dari berbagai pihak, sangatlah sulit bagi saya untuk menyelesaikan penyusunan penelitian ini. Saya mengucapkan terima kasih kepada semua pihak yang terlibat yang tidak dapat saya sebutkan satu persatu dalam penelitian ini.

\section{DAFTAR PUSTAKA}

1. Adelina, F. A., Widajanti, L. and Nugraheni, S. A. (2018) 'Hubungan Pengetahuan Gizi Ibu, Tingkat Konsumsi Gizi, Status Ketahanan Pangan Keluarga Dengan Balita Stunting (Studi pada Balita Usia 2459 Bulan di Wilayah Kerja Puskesmas Duren Kabupaten Semarang) Fariza', Jurnal Kesehatan 
Masyarakat (e-Journal), 6.

2. Apriyanto, D., Subagio, H. W. and Sawitri, D. R. (2016) 'Pola Asuh Dan Status Gizi Balita Di Kecamatan Lape, Kabupaten Sumbawa, Nusa Tenggara Barat', Gizi Pangan, 11(2), pp. 125-134.

3. Astuti, V. C. P., Kapantow, N. H. and Ratag, B. T. (2014) 'Hubungan Antara Pola Asuh lbu Dengan Status Gizi Anak Usia 1-3 Tahun Di Wilayah Kerja Puskesmas Walantakan Kabupaten Minahasa'.

4. Badan Ketahanan Pangan (2016) Buletin Pemantauan Ketahanan Pangan Indonesia. Jakarta.

5. Collins, C., Duncanson, K. and Burrows, T. (2014) 'Public Health Nutrition And Epidemiology A systematic review investigating associations between parenting style and child feeding behaviours', Journal of Human Nutrition and Dietetics. doi: 10.1111/jhn.12192.

6. Derseh, B. et al. (2018) 'Comorbidity, treatment outcomes and factors affecting the recovery rate of under -five children with severe acute malnutrition admitted in selected hospitals from Ethiopia: Retrospective follow up study', Nutrition Journal. Nutrition Journal, 17(1), pp. 1-8. doi: 10.1186/s12937018-0423-1.

7. Dinas Kesehatan Kabupaten Nganjuk (2017) 'Profil Kesehatan Kabupaten Nganjuk'. Available at: www.nganjuk.go.id.

8. Dinas Kesehatan Propinsi Jawa Timur (2017) Profil Kesehatan Propinsi Jawa Timur 2017. Surabaya: Dinas Kesehatan Provinsi Jawa Timur.

9. Hasibuan, Y. and Batubara, A. (2019) 'Mother' s Role and Knowledge in Young Children Feeding Practices on the Nutritional Status of Infant and Toddler'.

10. Kemenkes, R. (2018) Hasil Utama Riskesdas 2018. Jakarta: Kementrian Kesehatan Badan Penelitian dan Pengembangan Kesehatan.

11. Ningsih, S, Kritiawati, I. K. (2015) 'Hubungan perilaku ibu dengan status gizi kurang anak usia toddler', Pediomaternal Nursing.

12. Notoatmodjo, S. (2014) IImu Perilaku Kesehatan. Jakarta: Rineka Cipta.

13. Nursalam (2016) Metodologi Penelitian IImu Keperawatan Pendekatan Praktis Edisi 4. Jakarta: Salemba Medika.

14. Pratiwi, H., Bahar, H. and Rasma, R. (2017) 'Peningkatan Pengetahuan, Sikap, Dan Tindakan Ibu Dalam Upaya Pencegahan Gizi Buruk Pada Balita Melalui Metode Konseling Gizi Di Wilayah Kerja Puskesmas WuaWua Kota Kendari Tahun 2016', Jurnal IImiah Mahasiswa Kesehatan Masyarakat, 1(3).

15. Pratiwi, T. D. and Yerizel, E. (2016) 'Hubungan Pola Asuh Ibu dengan Status Gizi Balita di Wilayah Kerja Puskesmas Belimbing Kota Padang', Jurnal Kesehatan Andalas, 5(3).

16. Rahmawati, A. (2016) Hubungan antara Pengetahuan lbu tentang Gizi Seimbang dan Asupan Zat Gizi Makro pada Anak Usia 2-5 Tahun di Posyandu Gonilan Kartasura. Universitas Muhamadiyah Surakarta.

17. Rahma, A. C. and Nadhiroh, S. R. (2016) 'Perbedaan sosial ekonomi dan pengetahuan gizi ibu balita gizi kurang dan gizi normal', Media Gizi Indonesia.

18. Rahmawati, N. A. and Suciati, N. A. (2015) 'Hubungan Tingkat Pengetahuan Ibu Tentang Gizi Kurang Pada Balita Terhadap Kejadian Gizi Kurang Di Desa Penusupan Tahun 2013', 3.

19. Sari, M. R. N. and Ratnawati, L. Y. (2018) 'Hubungan Pengetahuan Ibu tentang Pola Pemberian Makan dengan Status Gizi Balita di Wilayah Kerja Puskesmas Gapura Kabupaten Sumenep Relation Between Mothers ' Knowledge About Feeding Method and Toddlers ' Nutritional Status in the Working Area of Puskesma', Amerta Nutr, pp. 182-188. doi: 10.20473/amnt.v2.i2.2018.182-188.

20. Sholikah, A., Rustiana, R. E. and Yuniasturi, A. (2017) 'Faktor - Faktor yang Berhubungan dengan Status Gizi Balita di Pedesaan dan 
Perkotaan', Jurnal Kesehatan Masyarakat, 2.

21. Siagian, C. M. and Halisitijayani, M. (2015) 'Mothers Knowledge On Balanced Nutrition To Nutritional Status of Children in Puskesmas ( Public Health Center ) In The District of Pancoran , Southern Jakarta 2014', International journal of current microbiology and applied sciences, 4(7).

22. Sodikin, Endiyono, fitria R. (2018) 'Hubungan Pengetahuan, Pola Pemberian Makan dan Pendapatan Keluarga terhadap Status Gizi Anak di Bawah Lima Tahun: Penerapan Health Belief Model', IImu Keperawatan Anak, 1, pp. 8-14.

23. Subarkah, T. (2016) Hubungan Pola Pemberian Makan Dengan Status Gizi Pada Anak Usia 1-3 Tahun Di Wilayah Kalijudan Kota Surabaya. Universitas Airlangga.

24. Susanti, Rika; Ganis, I. U. (2014) 'Hubungan Pengetahuan Ibu Tentang Gizi Dengan Status Gizi Anaka Usia 1-3 Tahun', JOM PSIK, 1.

25. Tung, $H$. and Yeh, M. (2013) 'Parenting style and child-feeding behaviour in predicting children' $\mathrm{s}$ weight status change in Taiwan', Public Health Nutrition, 17(5). doi: 10.1017/S1368980012005502.

26. UNICEF Indonesia (2012) Ringkasan Kajian Gizi Ibu \& Anak. Jakarta 